\title{
SENIORITY VS AGE OF SOUTH AFRICAN REGIMENTS
}

\author{
Col: L.A. Crook*
}

From time to time mutterings are heard about seniority of certain C.F. Regiments and it is particularly in Natal that this seems to occur, where there is friendly rivalry between supporters of the Natal Carbineers and the Durban Light Infantry.

Recently another letter appeared on the subject, this time in the April 1984 issue of "Springbok" the official newspaper of the SA Legion, when a Durban reader placed the Durban Light Infantry in number one position, pointing out that their motto is "Primus in Africa" (First in Africa), although he conceded that "the Natal Carbineers are the oldest Mounted Regiment".

Who is in fact oldest?

Which is the senior Regiment?

The second question is the easiest to answer but let us look at the factors that must be taken into account in order to reach finality on this vexed question.

These are:

(a) Which Arm of the Service is senior?

(b) Which Corps (of that Service) is senior, and finally.

(c) What are the foundation dates of units within that Corps.

In Britain the Royal Navy is the Senior Arm but in the S.A.D.F.:

(a) The Army is the senior Arm.

(b) The S.A. Artillery is the senior Corps in the Army.

(c) Field Branch Artillery is senior to Anti-Aircraft Artillery.

(d) The oldest SAA Field Branch unit is Cape Field Artillery and the latter is therefore the Senior Citizen Force unit in the R.S.A. Its bands are therefore the senior brass and pipe bands in the SADF (CF).

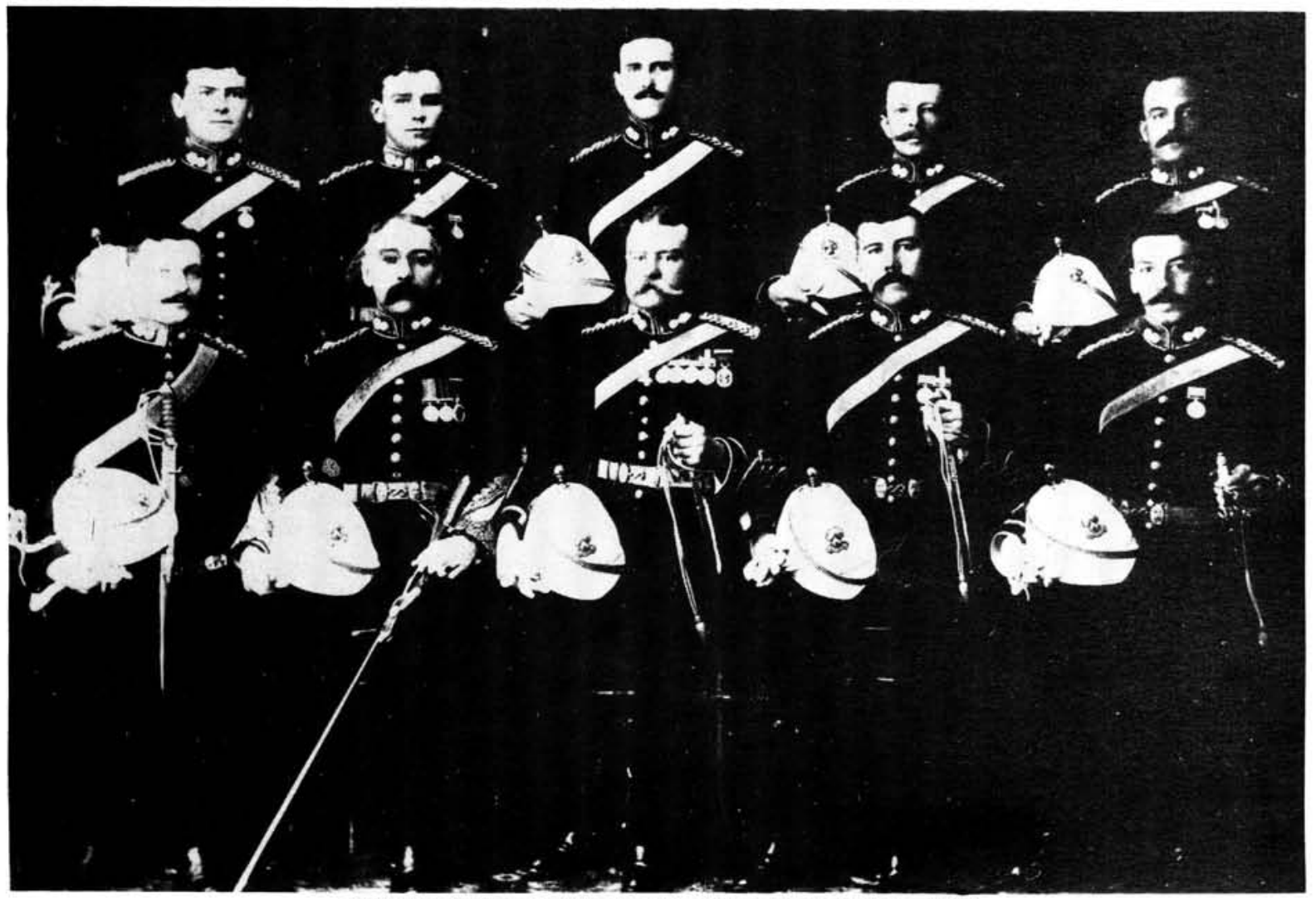

Officers of Prince Alfred's own Cape Field Artillery 1907. 
One could argue that seniority should extend to the SADF as a whole but the authorities have, rightly or wrongly, ruled that Permanent Force and National Service units take precedence over Citizen Force units, irrespective of Corps Seniority.

Back to "the Oldest". The contenders for the four oldest units (not in any order) are:

\author{
Natal Carbineers \\ Durban Light Infantry \\ Prince Alfred's Guard \\ Cape Town Rifles (Dukes) \\ Cape Field Artillery \\ Let us look at their backgrounds, one by \\ one.
}

\section{Natal Carbineers}

Professor A F Hattersley, the author of "Carbineer" "History of the Royal Natal Carbineers", wrote:

"Technically the inauguration of the regiment dates from the letter addressed to Sir Theophilus St. George by the Secretary to government, W C Sergeaunt, (on 2nd March 1855) conveying the Lieutenant-governor's sanction to its foundation."

$\mathrm{He}$ goes on to describe a volunteer unit known as the Umgeni Rangers enrolled in 1851 whom he considers the true forerunners of the Natal Carbineers with whom the Rangers merged in 1861. He writes also of the Royal Durban Rangers formed in April 1854 but whose charter was only proclaimed on 22nd February 1855 , as a unit who had been formed earlier than the Carbineers.

At this stage it might be as well to mention the problems faced by the military historian in trying to establish a true foundation date for a unit.

In many areas of South African (particularly the South Western and Eastern Cape and Natal) numbers of volunteers banded together in times of stress and formed units of varying strength. Many of these lasted only for the period of that emergency and died out after a matter of weeks. Some lasted for months and a number for a few years - such as the Royal Durban Rangers - but often one unit either survived and prospered or, as a result of the support and enthusiasm of those living in the area a new unit arose, phoenix like, and attracted many members of the earlier units.

The volunteer cause was supported in most cases by fairly prominent citizens. Their names are often found in records of early units and subsequently in later ones, sometimes like unit names were used and often there was confusion or indecision about the official name in newspapers, and even in official documents and in personal recollections. Hence we find the Cape Field Artillery, described within days in 1861, as the "Cape Artillery", the "Cape Town Volunteer Artillery" and as "Duprats Company of Foot Artillery". There was even once a second unit called "Cape Field Artillery" which existed at the same time as the present unit in about 1880 , to add to the confusion.

Likewise, there is seemingly little uniformity in policy in establishing an exact date of foundation, as will be seen later.

The historian's researches are sometimes further confounded by the fact that the "new" unit will have claimed its date of foundation as that of an older and long since defunct unit, because as one author has stated, in rather lordly fashion:

"... the response showed clearly that the men of the old Guard had merely been waiting. They had been there all the time and only needed serviceable rifles and a little encouragement to resume their activities ..."

Or by another stretch of the imagination a unit resuscitates a past name and claims the past regiment's seniority and traditions. An example of this is to be found in the Cape Garrison Artillery of Cape Town.

It would seem, therefore, from a strictly correct historical point of view that the date of foundation of a unit (and hence its seniority) should be the date from which it was officially accepted for service, as published in an official paper - whether it be Colonial or Government Gazette or SADF orders - and the second criteria is that since the foundation date, the unit should not have been dissolved or disbanded, i.e. there should not have been any break in service. Renaming of units is common in all armies and is of no consequence in the seniority stakes. 


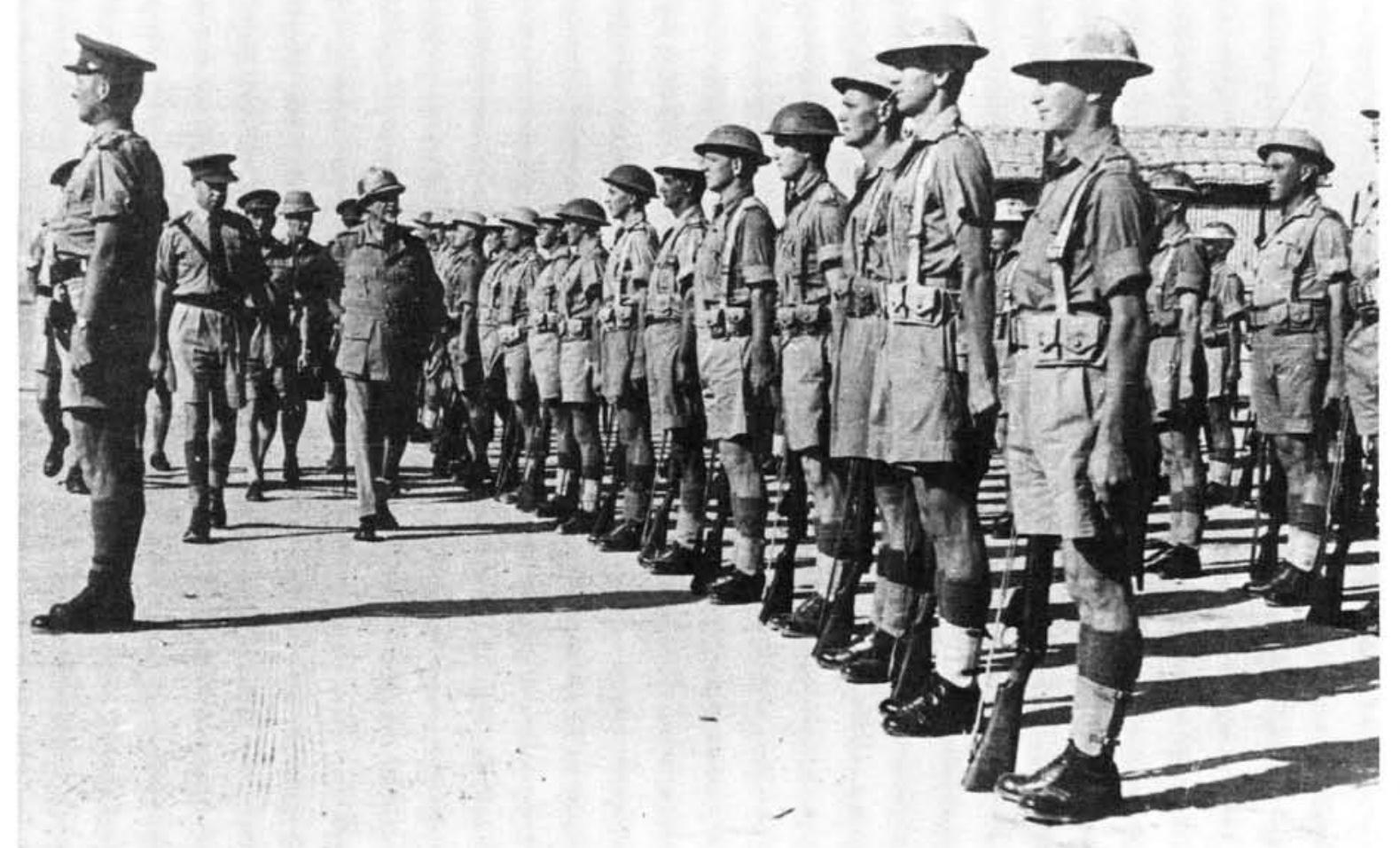

Gen Smuts visiting 1 SA Division. Inspecting guard of honour at Mersa Matruh. Detachments from Cape Town Rifles, Royal Natal Carbineers are included (76100152)

Hence, Professor Hattersley's date of inauguration for the Royal Natal Carbineers may not be correct but is nevertheless a fair one, especially in view of his remarks about the Umgeni Rangers.

It is interesting to recall that the Natal Carbineers came into existence as the result of a public meeting held in the Court House at Pietermaritzburg on 15 January 1855, when the name "Pietermaritzburg Irregular Horse" was chosen. When a second Troop was formed at Richmond on 7 February 1855, the title was replaced by that of "Natal Carbineers".

Their founding, "was gazetted on the 13th March 1855", according to the Durban Light Infantry history but this was the date that the Gazette was published and not the date from which the Carbineers were officially accepted for service by the Government.

The actual notice published in "The Natal Government Gazette", at Pietermaritzburg on Tuesday, March 13th, 1855 and authorised "by His Honour HENRY COOPER Esquire, Acting Lieutenant Governor, administering the Government of the District of Natal", read as follows:
"Whereas it is enacted by the Ordinance No 8, 1854, entitled "an ordinance to promote the Establishment of Volunteer Corps for the defence of the District", that it shall be lawful for every such Corps to make rules and buy laws regulating the duties of its members, the enforcing of discipline, the nature of its arms and equipments, the number and rank of its officers and members and its general place of rendezvous:-

And further that it shall be lawful for the Lieutenant Governor if he shall approve of such rules and bye-laws to sanction the same by a Proclamation under his hand, and that such rules and bye-laws shall thereupon have the force of law in the same manner as if the same were inserted in the said Ordinance:-

And whereas a corps called the "Natal Carbineers" has been formed and established at Pietermaritzburg, in the Country of Pietermaritzburg, and the said Corps having made the following rules and bye-laws for the regulation of the duties of its members, and the matters hereinbefore recited, which said rules and bye-laws have been duly submitted 
to me for sanction under the provisions of the Ordinance aforesaid:-

Now therefore I do hereby proclaim my sanction to the said Rules and bye-laws, and hereby direct their publication for general information.

\section{GOD SAVE THE QUEEN!}

Given under my hand at Pietermaritzburg in the District of Natal, this Sixth day of March, One Thousand Eight Hundred and Fifty-Five.

\section{Signed: H COOPER Lt. Coln. Commanding 45th Regiment Commandant}

The Rules and Bye-laws followed the above pronouncement which it should be noted includes the phrase "... has been formed and established at ..." i.e. formed prior to the date of the notice, which as seen above was 6th March 1855. One would presume therefore that the correct Date of Enrolment (foundation) would be close to that chosen by Professor Hattersley (2nd March, 1855) but what can we assume when reading Government Notice No. 14, 1855 dated at the Colonial Office, Natal, February 26th 1855, which reads:

"His Honour the Lieutenant Governor has been pleased to direct that ammunition for practice, and rations and ammunition whilst on actual service shall be issued at the cost of the local Government to the two Corps, called respectively the "Royal D'Urban Rangers" and the "Natal Carbineers", enrolled and embodied under the provisions of the 1st, 7 th and 8 th sections of the Ordinance No 8 , of 1854, entitled, "an Ordinance to promote the establishment of Volunteer Corps for the defence of the District."

\section{By Command of His Honour the Lieutenant Governor, WILLIAM C SERGEAUNT, Colonial Secretary}

The words underlined above have been so emphasised by the writer for the reason that they point to an earlier date of formation than that given by Professor Hattersley.
Unfortunately the source of material does not reveal the relevant date but it could well be the date on which the Natal Carbineers held their first meeting at Pietermaritzburg on 15th January 1855 . This selection of date would be in line with the policy adopted by the Cape Colony Government for deciding on the date of foundation.

It could not have been earlier than 15th January for in a Government Memorandum dated 6th January 1855 and published in the Gazette of 9th Janaury the Colonial Secretary on behalf of the Lieutenant Governor thanked all those who had taken part in the "late Expedition against the Amabaca Tribe". The list included the 73rd Regiment, Cape Mounted Rifles, Royal Durban Rangers and various Burgher forces. No mention, however, is made of the Natal Carbineers.

It is quite conceivable that the Date of Enrolment of this regiment, as it is so grandly called, could therefore well be the 15th of January 1855.

\section{Durban Light Infantry}

This unit claims in its published history lineal descent from the D'Urban Volunteer Guard "which began to take shape as early as May, 1854 ", but it bases its date of formation on a meeting held in the evening of 26th September, 1854, in the Magistrate's Room when apparently several people spoke of the necessity of forming an Infantry Corps and at which meeting "About 100 names were given in ...."

On 3rd October, 1854, a further meeting was held when "the rules were agreed upon, and the officers chosen, ...."

The official history of the unit reveals that the officers "were gazetted on the 27th August, 1855 , and dated the 1st August, 1855, ...", presumably the latter date meant their date of commission, and it goes on to say that, "The D'Urban Volunteer Guard, together with its Rules and Bye-Laws, had been proclaimed in the Gazette of the 30th January, 1855, as from the 27 th January, ...."

The Durban Light Infantry claims 26th September, 1854, as their date of origin and it would seem that the date is correct if Cape practice is followed. 


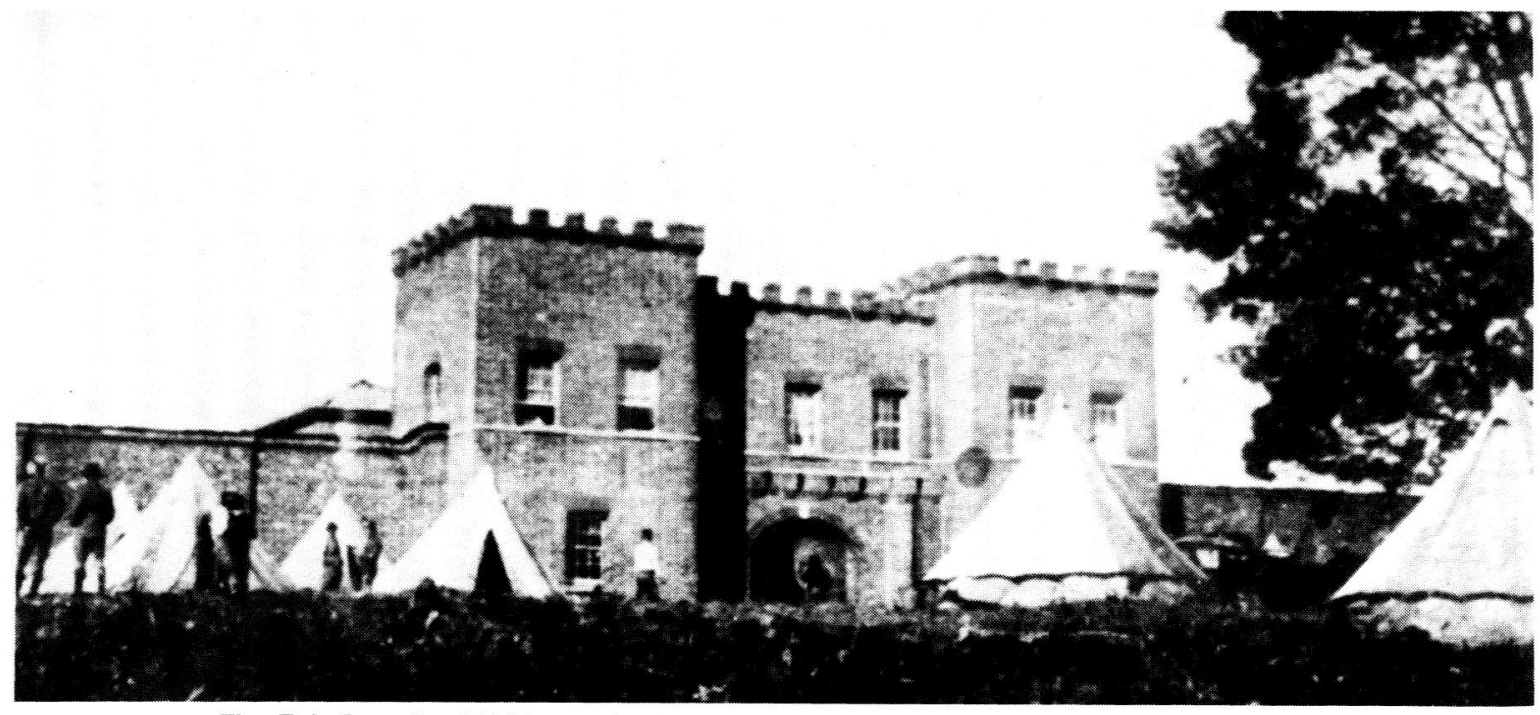

The Zulu Revolt of 1906 and the Durban Light Infantry Camp at Eshowe. (781005727)
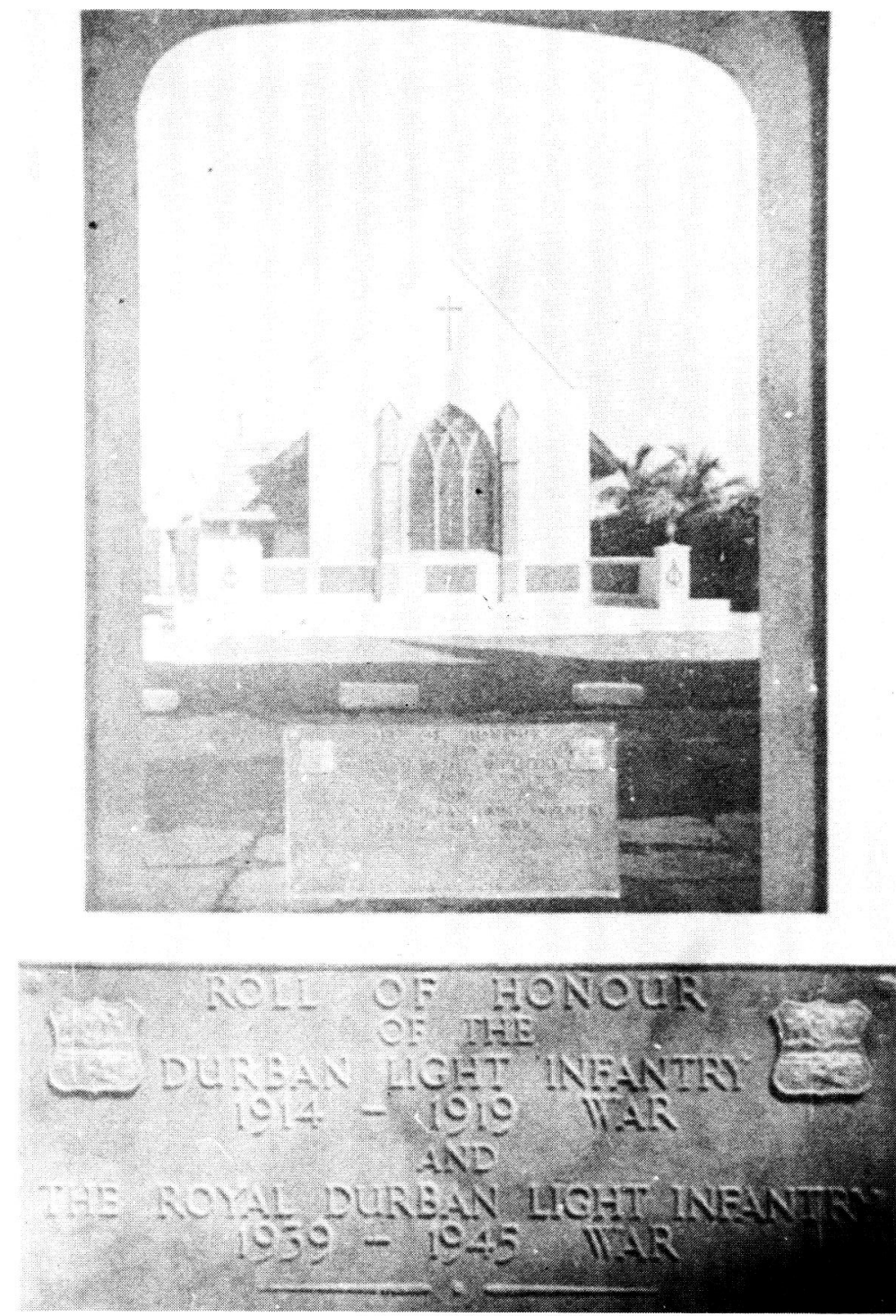

The church showing the roll of honour of both wars of the Durban Light Infantry and the Royal Durban Light Infantry. (761003221) 
In a supplement to the Natal Government Gazette dated January the 30th, 1855 , a proclamation by His Honor Benjamin Chilley Campbell Pine, Esquire, Lieutenant Governor, sanctioned on 27th January, 1855, the rules and bye-laws of the D'Urban Volunteer Guards.

The "1st Object" of the Rules and Bye-Laws formed by the Corps called "The D'Urban Volunteer Guards", read:

"In a country thickly inhabited by barbarous tribes it is generally determined on the part of the white population of this Town to associate together for mutual benefit and protection; and as the place is the Sea-port of the District, and the quarter whence the material assistance in the event of dissaffection of the natives must be obtained for the Community of the inner portions of Natal; we, under the provisions of the Ordinance No 8, 1854, agree to embody a Corps which has preliminary been in existance during the last three months as the "Durban Volunteer Guards".

This Corps is formed for Military Service; for defence of lives and property; as well as for the establishment of a base of retreat, should our neighbours be compelled to fall back upon the Sea-port for safety, and though of Military Character must be consider merely Protective in its main feature, and that the designation of this association be hereby retained."

There is an unfortunate twist to this story, however, for parades in late 1855 were apparently so poorly attended that at a special general meeting on 31st January, 1856, the 9 members present decided by vote to disband the unit. Despite an amendment to remain "only in abeyance", the Natal Mercury of 8th February, 1856, carried an order to members to return their arms and accountrements. Obviously the decision to disband had been carried and officially accepted.

A revival of interest in the Volunteer movement and a suggestion by the authorities that arms, accountrements and pay would be provided led to a meeting in Durban on 21st September, 1859, when it was agreed to form "a Volunteer Rifle Corps" for Durban to be called the Royal Durban Rifles. This name had later to be waived owning to the existence of the
Royal Durban Rangers (initials R D R) and so the proposed unit was instead provisionally named "Durban Rifle Guard".

The 100 or so enthusiastic volunteers who had indicated their willingness to join the unit, and who had apparently "begun drill in mufti", were unfortunately in for a rude shock for the Legislative Council refused to grant the rifles, accountrements and pay that had originally been suggested the Volunteers might receive.

A hard blow for the Volunteers, but in April, 1861 the Government had a re-think and decided that there was a need for defence. The Magistrate was instructed to call a meeting to find out what support could be expected if they supplied rifles but no pay. Such meeting was held on 30th April 1861, and the response was good. So much so that a muster was held on Saturday 6th May to sort members into Companies and to appoint a Committee to frame Rules and Regulations. A further meeting was held on 2nd July 1861, at which officers and Sergeants were elected.

Most of those so elected had previously been members of the D'Urban Volunteer Guard, but note that a committee had to be elected to frame Rules and Regulations - quite apart from the election of officials - clearly indicating that a completely new organisastion was being founded and formed.

Page 16 of "The Durban Light Infantry", Vol 1, reveals that "It was only in the course of time that the revived D'Urban Infantry Corps, gazetted as the "Durban Rifle Guard" on the 13th August, 1861, became familiarly known by that name".

Affinity for their original unit had obviously died hard but their leanings towards the old name could by no means be construed as conferring the apparent seniority of the old unit upon the new, not after a complete break of five years.

The author of the Durban Light Infantry history has a tendency to quote the date of publication of Government Gazettes. The Durban Rifle Guard had been formed under the provisions of Ordinance Number 11, 1855, and their rules and regulations dated 17th July 1861, signed by $\mathrm{C} J$ Cato, Major, was notified as being accepted by His Excellency John Scott, Lieutenant Governor, in a Government Notice 
signed at Pietermaritzburg on 7 August 1861 and which appeared in the Gazette published on 13th August 1861.

The Durban Rifle Guard had. therefore not been "gazetted on 13th August", for the notice quoted above stated in the preamble "... and whereas a Corps, called the "Durban Rifle Guard", has been formed and established at Durban ...."

The Government notice reveals that the Rules and Regulations, prior to acceptance by the Colonial Government, had been approved at a General Meeting of members held on 17th July 1861.

Following Cape of Good Hope Government policy the date of the meeting held on 30th April or 6th May would seem to be the Enrolment Date for the Durban Rifle Guard and of the present Durban Light Infantry, but let us consider the interesting comment made in an article which appeared in "The Nonggai" of August 1945, entitled "South African Artillery" and written by the late $\mathrm{Dr} \mathrm{H} \mathrm{H}$ Curson, a very well known military historian which reads:

"... the annual capitation grant of 5 s per man was withdrawn and the D R G (Durban Rifle Guard) ceased to exist in February $1869^{\prime \prime}$.

Dr Curson cites the "Historical Record of the Durban Volunteer Infantry Corps 1854-1904" published in Durban in 1905, as his source.

According to the history of the Durban Light Infantry, the Colony of Natal in 1868 was in debt to an amount of over $\$ 100000$ and the Volunteer grant was cut from $£ 3000$ to $£ 1500$. The D R G determined to carry on without a capitation grant as long as possible. A Commission had been appointed in that year to enquire into the Colonial Forces and Defence and its report completed in late March 1869 was not altogether encouraging.

Meanwhile the cut in financing was strangling the Volunteer units and in May 1869, the D R G offered for sale "a flagstaff, an ensign, marking flags, a target, a small wooden house with iron roof behind the butts, the instruments recently in use by the band and a quantity of music suitable for Military Bands".

The Natal Government Gazette of 9th November 1869 , notified disbandment of the Corps and the Gazette of 14th December announced the disbandment of the Royal Durban Rangers.

The notice, Government Notice No 151, 1869 dated November 5 th, 1869 , was quite specific on this matter for it read:

"The Durban Rifle Guard having this day been disbanded, His Excellency the Lieutenant Governor directs it to be notified that all members who belonged to the said Corps are directed to return on or before the $23 \mathrm{rd}$ instand in good order and complete, all arms and other articles the property of the Government, entrusted on their charge ...."

The notice went on further to specify the place of delivery of such equipment, the fact that receipts would be issued, that deficiencies would have to be made good and concluded with the warning that legal proceedings would be instituted against those who did not comply.

In effect, the death notice of a Regiment.

The Artillery Company of the Durban Rifle Guard, which refused to be extinguished either by finance or decree, was revived as the Durban Volunteer Artillery on 3rd June 1879 , and it continues today as the Natal Field Artillery.

The financial fortunes of the Colony of Natal gradually improved and increased revenue permitted in 1872 the introduction of the Volunteer Law, 1872.

All existing units were required to confirm acceptance of the provisions of the new Law and Volunteer Notice No. 5 dated January 17 th, 1873, confirmed that the following existing Corps had done so:

Natal Carbineers
Natal Frontier Guard
Weenen Yeomanry Cavalry
Victoria Mounted Rifles
Richmond Mounted Rifles
Alexandra Mounted Rifles
New Germany Rifles
Pietermaritzburg Rifles
Durban Volunteer Artillery

As a result of the new dispensation in terms of the Law volunteer enthusiasts, including mem- 


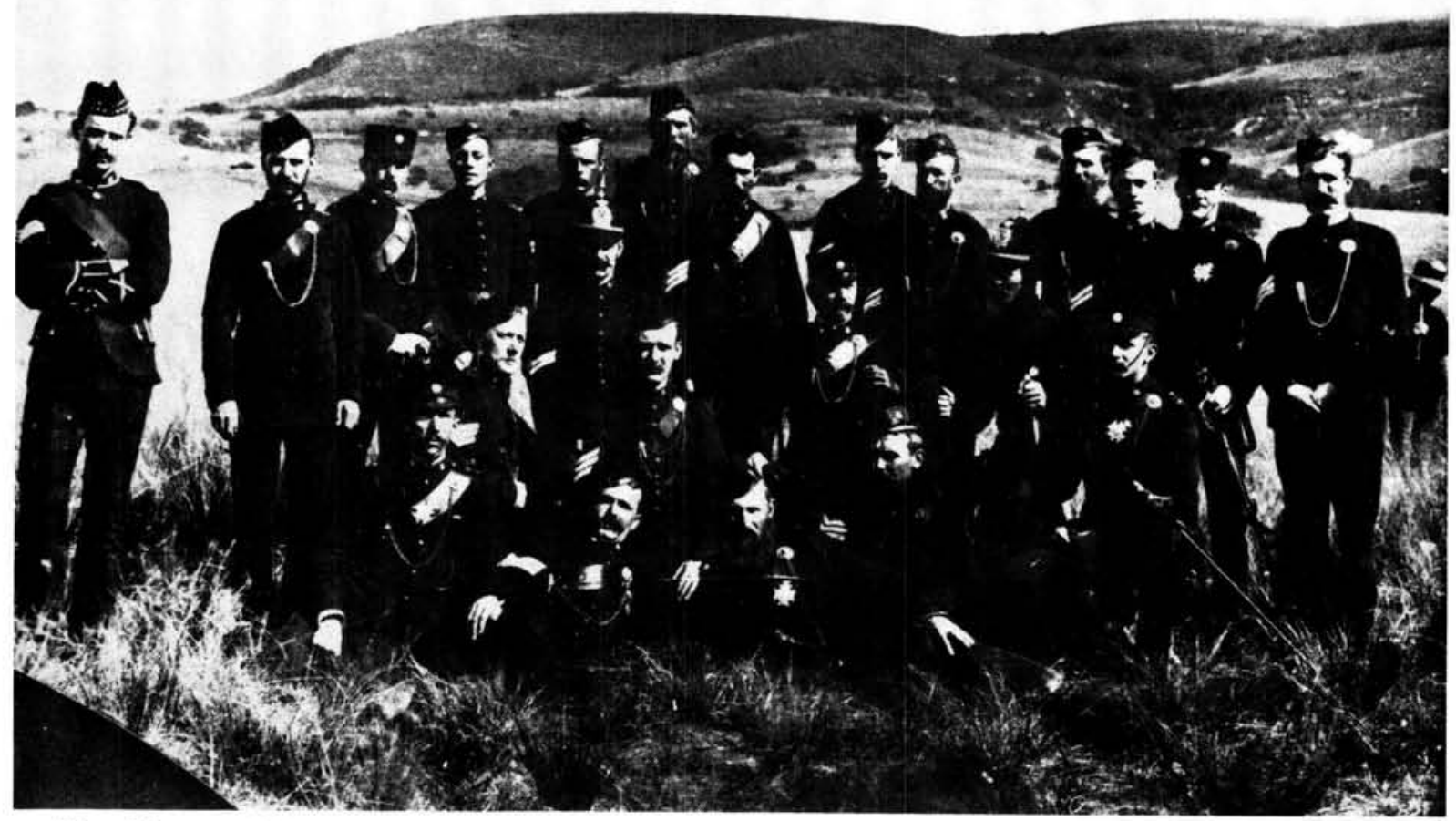

The officers and Non Commissioned officers of the Royal Rifles (left half) Pinetown Camp, 1890. (841003489)

bers of the former Durban Volunteer Guard, met on 4th March, 1873, and decided to proceed with the organisation of a Corps. Names were taken and a second meeting was held on Saturday, 15th March for further enrolment.

Another meeting was held on the 29th of the month at which the Surgeon was elected (all over posts were held in obeyance) and the rules and bye-laws approved. Various members were later elected to what are today called "key-posts".

No time was lost by the Lieutenant-Governor in recognising the Corps and in Volunteer Notice No. 16, 1873 dated 2nd April, 1873, published in the Gazette of 8th April, the Governor directed it to be notified that he had been pleased to accept the services of certain persons forming themselves into a Corps under Volunteer Law No. 15, 1872, and under the name of the "Royal Durban Rifles".

The first commissions were issued to Edward Randles, Esq., as Captain Edward Pickering, Esq., as 1st Lieutenant, Julius Schultz, Esq., MD, as Surgeon and James Harrison, Esq., as Quarter Master and these were made known in Notice No. 17, 1873, dated 4th April of that year.
By Proclamation on the 8th May 1873, "His Excellency Thomas Milles, Esquire, Lieutenant Colonel, Administrator of the Government in and over Natal, Vice-Admiral of the same, and Supreme Chief over the Native Population", approved Rules and Bye-Laws of the Royal Durban Rifles.

From 1873 the unit has continued in existence uninterruptedly, despite amalgamation with the Natal Royal Rifles in 1889, a break from that unit six years later, and several changes of name, including the addition of the title "Royal" in 1935 and a reversion to "Durban Light Infantry" in 1961.

"Primus in Africa", does not necessarily mean the first to be formed. Even the newest unit could not be faulted for referring to itself as the "Best in Africa", and this is perhaps what those old Volunteers meant when choosing their Motto.

\section{Prince Alfred's Guard}

The history of the P A G written by the well known military historian, Colonel Neil Orpen, gives the date of formation of the unit and of its acceptance for service as 19th September, 1856. Previous books, written in 1906 and 1939 confirm this date. 
The unit was formed as the Port Elizabeth Rifle Corps and the usual preliminary meeting to consider the formation of a Volunteer Corps had been held in the Commercial Exchange Room on the Market Square, Port Elizabeth, on 22nd August 1856.

Government Notice No 313 of 16th September 1857 confirms the Date of Enrolment as $19 \mathrm{Sep}$ tember 1856 with the date of approval of Regulations as 23rd October, 1856.

Prince Alfred's Guard has continued service as a unit to this day without a break.

\section{Cape Town Rifles (Dukes)}

An inaugural meeting of those who wished to join the "Cape Rifle Corps" was held at noon on Wednesday, 28th November, 1855, in the side room of the Commercial Exchange. The two men who had initiated the meeting. The Hon. William Hope, the Colonial Auditor-General and the Chevalier Alfred Duprat had, however, written to the Governor, Sir George Grey, eight days previously and the meeting had been called "to hear the Governor's approving reply to the letter".

The 28th November, 1855, is therefore taken as the foundation date of the Cape Town Rifles
(Dukes) and this is confirmed by the following entry in the Cape of Good Hope Government Gazette of Tuesday, September 22, 1857:

\section{"GOVERNMENT NOTICE - NO. 313, 1857} Colonial Office, Cape of Good Hope

16th September, 1857

His Excellency the Governor has directed the publication of the subjoined list of those Volunteer Corps enrolled or now acting under the Act of the Colonial Parliament, No 25, of 1856, entitled "An Act for Promoting the Formation of Volunteer Corps", whose Rules and Regulations have been submitted to, and approved by, His Excellency, in accordance with the provisions of that Act, from which the necessary Returns have been received up to the present date.

His Excellency has further directed the publication of the names and dates of appointment of the Officers of each Corps.

By Command of His Excellency the Governor

Rawson W Rawson Colonial Secretary

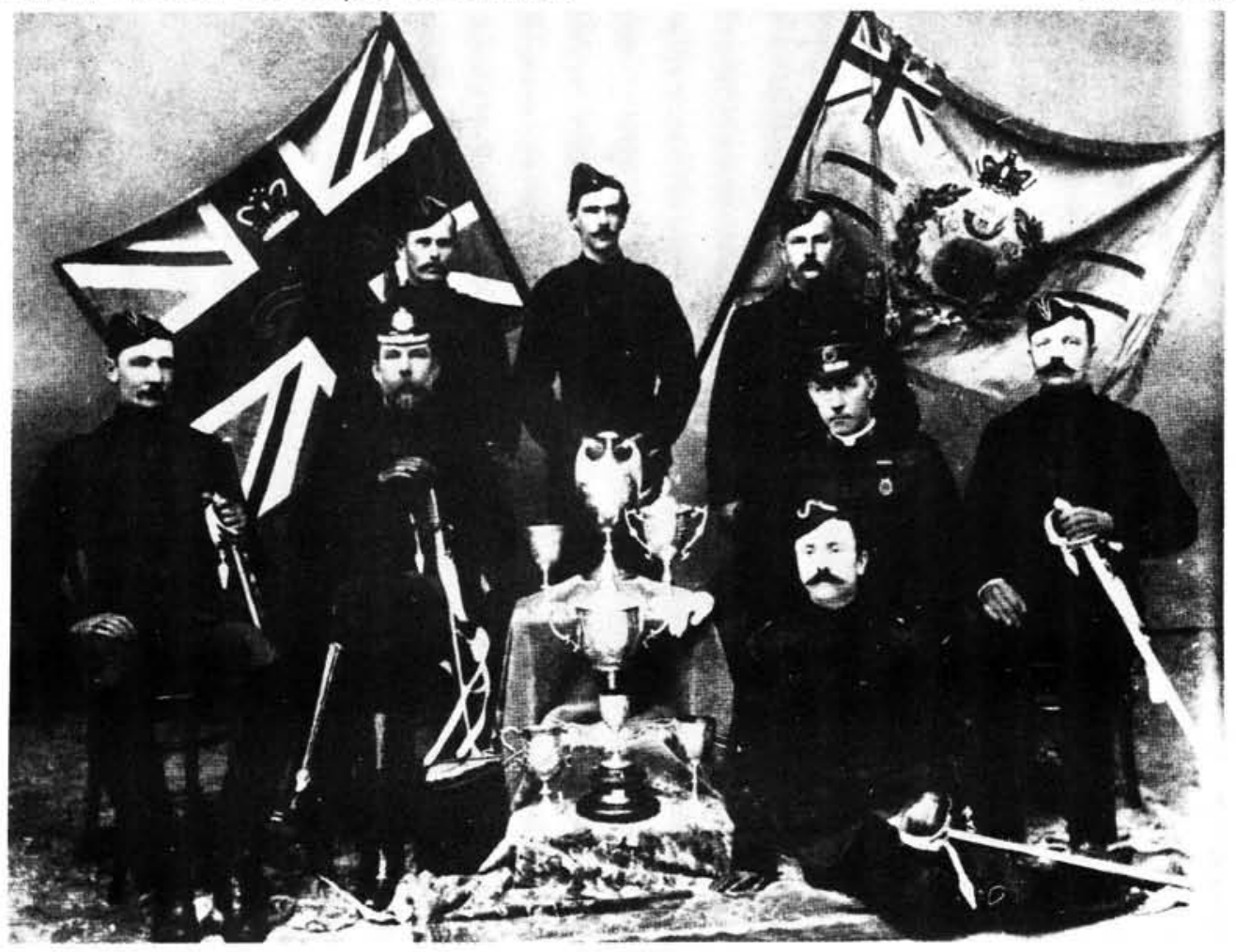

Officers of Prince Alfred's Guard 1899. The Queen's and Regimental colours are in the background. (841003490) 
1. CAPE VOLUNTEERS

Colonel Commandment, Hon'ble

William Hope, Esquire,

8th December, 1855

\section{CAPE TOWN RIFLE CORPS - $(2 \mathrm{com}$ - panies)}

Date of Enrolment

Date of Approval of

Regulations

Nov. 28,1855

Numerical Strength on

Sept 9, 1857

Dec. 13, 1855

$148^{\prime \prime}$

Then follows a list of officers and dates of appointments from which it is interesting to note that the Adjutant and Quarter-master were appointed from December 3, 1855 while the two men who had paved the way for the formation of the unit were appointed only from December 8, 1855.

Included below were similar details for other Volunteer units in Cape Town, Stellenbosch, Worcester, Graaff-Reinet, Swellendam, George, Paarl, Port Elizabeth and the Lange Kloof, all of whom were obviously formed prior to the date of the Notice and who would today have enjoyed seniority over most present Citizen Force Units, had they continued in existence. A further Notice on 1st October 1857, included units at Hope Town, Malmesbury and Oliphant's Hoek.

\section{Cape Field Artillery}

This "... old and well known unit ..." to quote General J C Smuts who spoke of the loss of the entire 2nd Battery at Tobruk in June 1942, has suffered fifteen changes in name since it was formed at a meeting held in the Old Town House, Greenmarket Square, Cape Town on 26th August, 1857, on which date the first members of the Cape Town Volunteer Artillery were enrolled under the command of Major the Chevalier Alfred du Prat, K C C, former Second in Command of the Cape Town Rifle Corps.

Quicker into action than most they held their first official training parade within 6 weeks, on 2nd October, 1857, complete with two 6 pdr brass guns. Five days later they were present at a Volunteer Review at Stellenbosch.

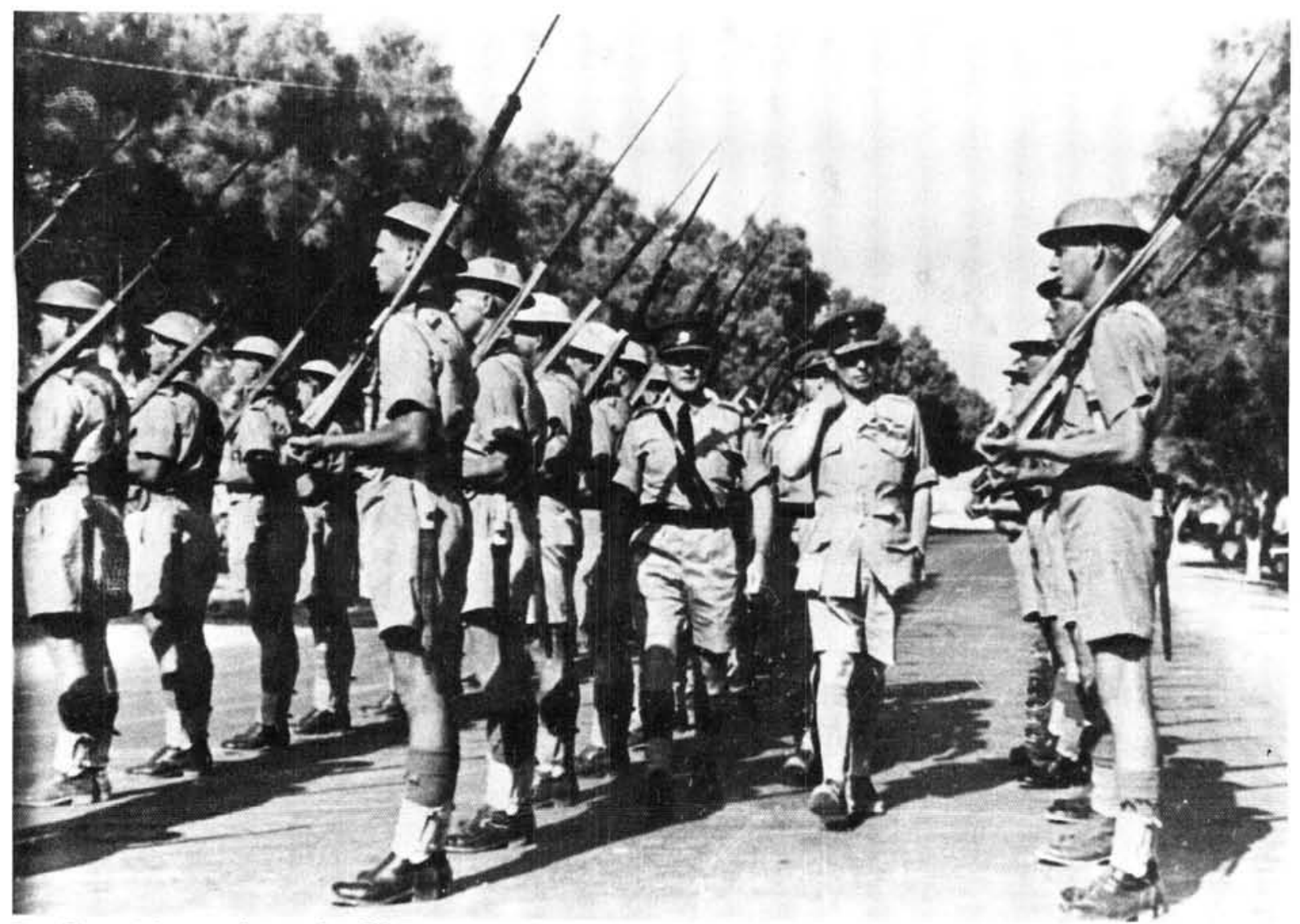

The King of Greece inspecting SA Troops at Mersa Matruh consisting of troops of 1 Transvaal Scottish, Cape Town Rifles and Royal Natal Carbineers. (7610001536) 
Investigation of Cape of Good Hope Government Gazettes, and the 1860 edition of the well known Cape of Good Hope Almanac reveals that the date 26th August, 1857, was officially recorded as the Enrolment Date, or foundation date of the unit, and Chevalier A du Prat was approved as Major Commanding, one company of Cape Town Artillery, from the same date.

Of this unit's date of foundation there is therefore no doubt.

To sum up, the officially accepted date of formation of Volunteer units in the Cape Colony appears to have been the date of the first meeting on which members were enrolled (known as the Date of Enrolment), except in the case of Prince Alfred's Guard. Perhaps in the latter case use of the phrase "usual preliminary meeting" in a preceeding paragraph is incorrect as their meeting on 22nd August, 1856 , may well have been a preliminary meeting, with the usual enrolment meeting having taken place on the 19th September, 1856, the Enrolment Date confirmed in the Government Gazette.

In Natal we find the date of a letter being used (Natal Carbineers) and, apparently, the enrolment date of a previous unit, as is shown in the table below:

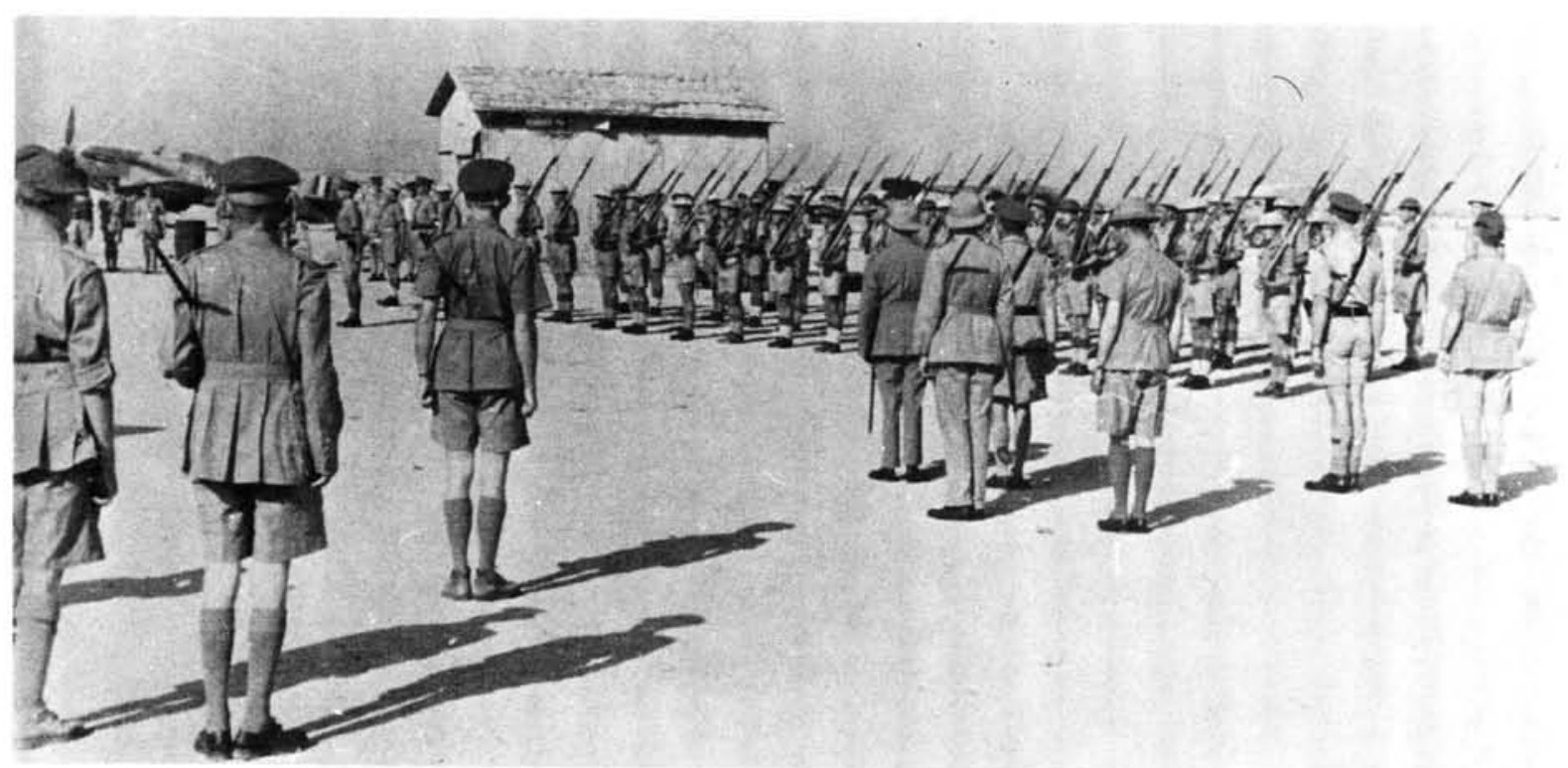

Gen Smuts leaving Mersa Matruh. Guard of honour at the Airfield with detachments of 1 Transvaal Scottish, Royal Natal Carbineers and Cape Town Rifles. (761002121)

D’Urban Volunteer Guard

Natal Carbineers

Cape Town Rifles (Dukes)

Prince Alfred's Guard

Cape Field Artillery

Durban Light Infantry

\begin{tabular}{|c|c|c|}
\hline \multicolumn{3}{|c|}{ Date of Formation } \\
\hline $\begin{array}{c}\text { Proclaimed } \\
\text { Date }\end{array}$ & $\begin{array}{c}\text { Inaugural } \\
\text { Meeting }\end{array}$ & Other \\
\hline 27 Jan 1855 & 26 Sept 1854 & \\
13 Mar 1855 & 15 Jan 1855 & 2 Mar 1855 \\
28 Nov 1855 & 28 Nov 1855 & \\
19 Sept 1856 & 22 Aug 1856 & \\
26 Aug 1857 & 26 Aug 1857 & \\
2 Apr 1873 & 4 Mar 1873 & \\
\hline
\end{tabular}

The dates selected by the author as the date of foundation of each of these units would be:
1. Natal Carbineers
2. Cape Town Rifles (Dukes)
- 15 January 1855
- 28 November 1855

3. Prince Alfred's Guard - 19 September 1856
4. Cape Field Artillery - 26 August 1857

5. Durban Light Infantry - 4 March 1873

'Col. L.A. Crook, SM, JCD, joined the Citizen Force on 1 July, 1949 and commanded Cape Field Artillery from 1973 to 1979 . He is presently Deputy Director Artillery (Field) (CF).

\section{Sources: Literature}

Hattersley, Prof A.F.: Carbineer - History of the Royal Natal Carbineers Martin, A.C.: The Durban Light Infantry Vol 1, 1854-1934

McKenzie, Angus G.: The Dukes; A History of the Duke of Edinburg's Own Rifles 1855-1956

Orpen, Neil: Gunners of the Cape; the story of the Cape Field Artillery Orpen, Neil: Prince Alfred's Guard 1856-1966

\section{Publications}

Cape of Good Hope Almanac: 1858, 1859, 1860

Cape of Good Hope Government Gazettes: 1855, 1856, 1857, 1860

Natal Government Gazettes: 1856, 1860, 1861, 1869, 1873 